\title{
Clinical and nutritional aspects of changes in acute-phase proteins during inflammation
}

\section{By A. FleCK, Department of Chemical Pathology, Charing Cross and Westminster Medical School, St Dunstan's Road, London W6 8RF}

Various aspects of the systemic effects of inflammation in man have been reviewed recently, including the effects of inflammation on the microcirculation, endocrine changes, energy and substrate metabolism after trauma, and assessment of nutritional status (Little \& Frayn, 1986).

The present paper concentrates on the changes in plasma proteins and their metabolism and distribution during inflammation and compares these with the effects of nutritional depletion on plasma proteins.

For some years now the systemic and clinical changes observed during the early stages of an infectious illness or after trauma have been referred to as the acute-phase response'.

\section{The acute-phase response}

The acute-phase response was initially the term applied to the phenomena, including pyrexia, rigors, weakness and leucocytosis, observed in patients during the acute or early stages of an infectious illness. Recently Koj \& Gordon (1985) summarized it as 'an early and unspecific highly complex reaction of the animal organism to a variety of injuries, such as bacterial or parasitic infection, mechanical or thermal trauma, malignant growth or ischaemic necrosis'. The acute-phase response could be regarded as the systemic, in contrast to the local, effects of inflammation (Belfrage, 1963). There is clearly close similarity between the sequelae of an acute infection and the changes in metabolism after trauma described by Cuthbertson $(1932,1942)$.

The acute-phase reaction was the term applied by Tillet \& Francis (1930) to the precipitin reaction they observed when a pneumococcal extract was added to the serum from patients in the acute phase of pneumonia.

It was shown that this reaction was due to a protein, referred to as $\mathrm{C}$-reactive protein (CRP), and further investigation showed that the protein could be demonstrated in many acute illnesses but could not be detected in the plasma or serum of normal individuals (MacLeod \& Avery, 1941).

The chemistry and phylogenetic aspects of CRP have been reviewed by Baltz et al. (1982): it is one of the pentraxins, and occurs in a wide variety of species including man and the Limulus crab.

\section{Acute-phase (plasma) proteins}

A large number of plasma proteins have been referred to as acute-phase (plasma) proteins (Table 1). For some time it has been the custom to refer to those which increase in concentration after injury as 'positive acute-phase proteins' (which include CRP, alpha ${ }_{1}$-antitrypsin, alpha ${ }_{1}$-acid glycoprotein and fibrinogen) and to those which decrease in concentration as 'negative acute-phase proteins' (which include albumin and transferrin) (see Koj (1985) and Fleck et al. (1985a)).

Possibly the earliest observation of a change in plasma proteins in acute illness was noted by Hunter in 1794, who in his treatise on gunshot wounds refers to increases in the fibrinous component of blood after injury. Changes in plasma proteins following burning injury have been described by Davies (1982) and were described after trauma by 
Table 1. Plasma protein changes after injury in man

\begin{tabular}{|c|c|c|c|c|}
\hline & Molecular wt & $\begin{array}{l}\text { Normal plasma } \\
\text { concentration } \\
(\mathrm{g} / \mathrm{l})\end{array}$ & $\begin{array}{c}\text { Electrophoretic } \\
\text { mobility }\end{array}$ & $\begin{array}{l}\text { Concentration } \\
\text { change in } \\
\text { trauma }\end{array}$ \\
\hline \multicolumn{5}{|l|}{ 'Positive' acute-phase proteins } \\
\hline C-reactive protein & 105000 & $<0.01$ & $\gamma$ & $\uparrow \uparrow \uparrow$ \\
\hline Serum amyloid $\mathrm{A}$ & $11-14000$ & about 0.01 & Binds to $\mathrm{HDL}_{3}$ & $\uparrow \uparrow \uparrow$ \\
\hline Alpha $_{1}$-acid glycoprotein & 44000 & 1 & $\alpha_{1}$ & $\uparrow \uparrow$ \\
\hline Alpha $_{1}$-antichymotrypsin & 68000 & 0.4 & $\alpha_{1}$ & $\uparrow \uparrow$ \\
\hline Alpha $_{1}$-antitrypsin & 54000 & 2 & $\alpha_{1}$ & $\uparrow \uparrow$ \\
\hline Fibrinogen & 340000 & 2 & $\mathbf{B}_{2}$ & $\uparrow \uparrow$ \\
\hline Haptoglobin 1-1 & 99000 & 2 & $\alpha_{2}$ & $\uparrow$ \\
\hline Caeruloplasmin & 130000 & 0.22 & $\alpha_{2}$ & $\uparrow$ \\
\hline Complement factor C3 & 180000 & $1 \cdot 3$ & $\beta_{2}$ & $\uparrow$ \\
\hline Alpha2-macroglobulin & 820000 & $2 \cdot 7$ & $\alpha_{2}$ & $\longleftrightarrow$ \\
\hline Haemopexin & 57000 & $0 \cdot 85$ & $\boldsymbol{\beta}_{1}$ & $\longleftrightarrow$ \\
\hline \multicolumn{5}{|c|}{ 'Negative' acute-phase proteins } \\
\hline Albumin & 66000 & 40 & & $\downarrow$ \\
\hline Pre-albumin (transthyretin) & 55000 & 0.25 & Pre-albumin & $\downarrow$ \\
\hline Retinol-binding protein & 21000 & 0.045 & Binds to pre-albumin & $\downarrow$ \\
\hline Transferrin & 77000 & $2 \cdot 3$ & $\beta_{1}$ & $\downarrow$ \\
\hline
\end{tabular}

$\mathrm{HDL}_{3}$, high-density lipoprotein; $\uparrow$, increase; $\downarrow$, decrease; $\longleftrightarrow$, no change.

Cuthbertson \& Tompsett (1935). The changes after acute infection were extensively investigated by Belfrage (1963), and the electrophoretic pattern of acute infection was described by Sunderman (1964). Our knowledge of changes in plasma proteins in injury and disease has been extensively reviewed by Owen (1967).

\section{General factors affecting the concentration of plasma proteins}

Several causes of changes in the concentrations of plasma proteins can be distinguished.

Although there are increases in fibrinogen, alpha ${ }_{1}$-antitrypsin and caeruloplasmin and decreases in albumin during pregnancy (Ganrot, 1972) and in women taking certain contraceptive pills (Laurell et al. 1968), the lack of an increase in CRP in these situations suggests that an acute-phase response does not normally accompany pregnancy and that oestrogens and progestagens may influence the concentration of certain plasma proteins, inducing changes in some ways similar to those of the acute-phase response. Severe hypoalbuminaemia not directly due to an acute-phase response occurs in nephrosis and protein-losing enteropathy. Simple physiological causes of changes in plasma proteins were reported by Böhme (1911): plasma protein concentration decreases by $15 \%$ within about $30 \mathrm{~min}$ of lying down relaxed after standing up, and increases with exercise, paralleling the increase in blood pressure. These changes were subsequently confirmed as being due to changes in the distribution of body fluid leading to changes in plasma volume (Thompson et al. 1928).

A recent summary of the factors influencing the concentration of plasma proteins and methods of investigating their metabolism and distribution is available (Fleck, 1985).

\section{Mechanism of the acute-phase protein response}

There is now wide agreement that after an acute injury there is a delay of about $8 \mathrm{~h}$ before the well-known increases in the positive acute-phase proteins occur (Fleck et al. 

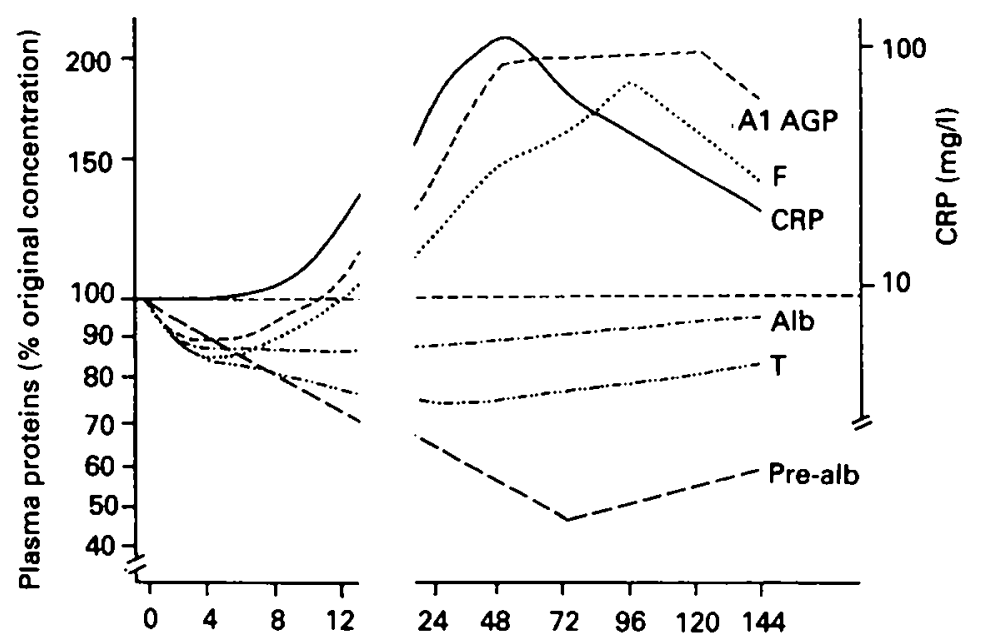

Fig. 1. Changes in concentration of plasma proteins after injury or inflammation. A1 AGP, alpha -acid $^{-}$ glycoprotein; F, fibrinogen; CRP, C-reactive protein; Alb, albumin; T, transferrin; Pre-alb, pre-albumin. The change in CRP concentrations is plotted on a logarithmic scale.

$1985 a$ ). In contrast, the decreases in the negative acute-phase proteins occur immediately on injury (Myers et al. 1984) (Fig. 1). This implies that at least two mechanisms may be involved.

Positive acute-phase protein response. Kampschmidt et al. (1973) and Wannemacher et al. (1975) described the preparation and properties of a supernatant fraction from activated leucocytes which they termed leucocyte endogenous mediator which could induce the synthesis of acute-phase proteins in rat liver and changes in RNA synthesis. The active component was a peptide of about 14000 molecular weight (Kampschmidt, 1981). The preparation could induce pyrexia in animals and thus contained endogenous pyrogen (EP). It could also activate lymphocytes, i.e. showed lymphocyte activating factor activity, and was later designated interleukin-1 (IL-1) (Dinarello, 1984). A few years later the amino acid sequence of IL-1 was determined and synthetic preparations of recombinant IL-1 became available for study (Auron et al. 1984; Lomedico et al. 1984; March et al. 1985).

Studies on other polypeptide cytokines including tumour necrosis factor (TNF) and hepatocyte stimulating factor (HSF) were being carried out in parallel with the investigations of properties of IL-1. When the effects of IL-1, TNF and HSF have been studied using either cultures of hepatocytes or human hepatoma cell lines it has become clear that only HSF induces the full acute-phase response (Koj et al. 1984, 1987), and that IL-1 and TNF lead to increased synthesis of only a few, and not the major, (i.e. CRP and serum amyloid $\mathbf{A}$ in man) acute-phase proteins.

Recently Gauldie et al. (1987), using both human hepatoma HepG2 cells and rat hepatocytes, showed that interferon $\mathbf{B}_{2}$ which is identical with $\mathrm{B}$-cell stimulatory factor type 2 and has been referred to as interleukin-6 (IL-6), regulates the major acute-phase protein response of the liver.

In our own studies (Myers \& Fleck, 1988) we confirmed that the delay of about $8 \mathrm{~h}$ 
after injury before increases in the concentrations of acute-phase proteins were detectable in man, and in experimental rats and mice, could be reduced to $2 \mathrm{~h}$ in mice by injecting a preparation of leucocyte endogenous mediator.

Injecting a preparation of the supernatant fraction from a B-cell lymphocyte cell line intravenously into patients induced rigors in 15-30 min and increases in CRP within $6 \mathrm{~h}$ (Myers, 1987). We suggested (Myers \& Fleck, 1988) that such observations were consistent with a sequence of steps. These could include the release of a series of cytokines by various cells including IL-1, leading to the release of IL-6. More recently, however, Shenkin et al. (1988) have shown that increases in IL-6 activity can be detected within $1 \mathrm{~h}$ of the skin incision at the beginning of a surgical operation. Our understanding of the mechanisms of the induction of the increased synthesis of the positive acute-phase proteins is still incomplete.

Negative acute-phase response. In a moderate or severe injury the concentrations of albumin, transferrin, retinol-binding protein and pre-albumin fall immediately (see Fig. 1). The concentration of albumin is usually lowest about $5 \mathrm{~d}$ after injury (Ballantyne \& Fleck, 1973a). Less severe injury, however, may not lead to detectable changes in albumin concentration.

The pattern of change is similar during infections (Belfrage, 1963). These early changes are most likely to be due to changes in the distribution of fluid and plasma proteins in the body, rather than to immediate changes in synthesis or catabolism of the protein.

The fractional (i.e. the fraction of the intravascular pool) rates of catabolism and synthesis of albumin are $0 \cdot 1 / \mathrm{d}$ or $10 \% / \mathrm{d}$, whereas the fractional exchange with the tissue spaces is $1.2 / \mathrm{d}$ or $120 \% / \mathrm{d}$ (Rossing, 1967). Consequently a relatively small increase (e.g. $10 \%$ ) in the exchange of albumin with the tissue spaces could lead to a fall in albumin concentration greater than that caused by complete inhibition of synthesis. Although the fractional rate of synthesis of pre-albumin is about $59 \% / d$, its rate of exchange with tissue spaces is $190 \% / d$ (Vahlquist et al. 1973), i.e. about three times the fractional rate of synthesis and catabolism, so that increased exchange of pre-albumin with tissue spaces is also likely to be a significant factor in its decrease in concentration after injury.

There are several possible mechanisms which could lead to an increase in vascular permeability (Casley-Smith, 1980) which is the most likely cause of the observed prompt decrease in the concentrations of the negative acute-phase proteins. As soon as tissue is damaged the release of cell contents leads to the stimulation of leucocytes, macrophages and mast cells with, in turn, the release of cytokines such as IL-1, IL-2 and TNF.

The 'contact system' (Cochrane \& Griffin, 1982) may also be activated, which leads to the activation of the clotting cascade and the local release of bradykinin which may induce marked increases in vascular permeability. TNF may also cause increased vascular permeability (Beutler \& Cerami, 1987).

Several components of complement when activated, e.g. C3a and C5a (McPhaden \& Whaley, 1985), are also known to be very vasoactive, inducing increased vascular permeability.

Thus, although the actual mediators of increased vascular permeability after injury in man may not yet be known, evidence is accumulating that several very vasoactive substances are likely to be present at various stages after injury, and some (e.g. TNF) will be in the circulation within a few minutes. Some of the factors which could affect the metabolism and distribution of plasma during inflammation are illustrated in Fig. 2.

A more direct method of assessing the extent of loss of albumin to the tissue spaces than simply measuring its concentration is available. This is known as the transcapillary (or transvascular) escape rate (TER) (Parving \& Gyntelberg, 1973). It is readily 


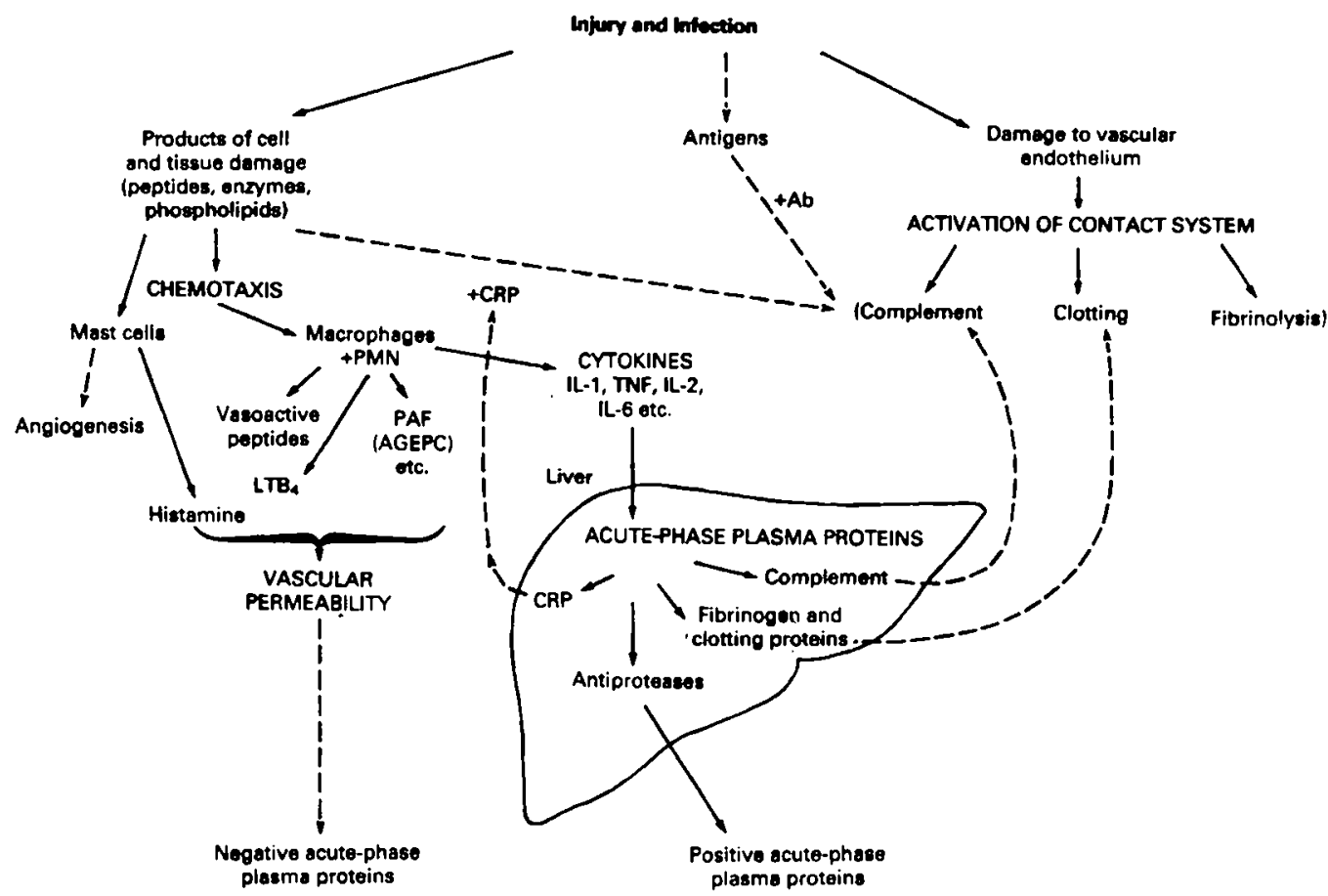

Fig. 2. Possible mechanisms of the changes in plasma proteins after injury or inflammation. Ab, antibody (e.g. IgG); IL-1, IL-2 and IL-6, interleukin-1, -2 and -6 respectively; TNF, tumour necrosis factor (cachectin); PMN, polymorphonuclear leukocytes; PAF, platelet activating factor; AGEPC, acetyl glyceryl ether phosphorylcholine; $\mathrm{LTB}_{4}$, leukotriene $\mathrm{B}_{4} ; \mathrm{CRP}, \mathrm{C}$-reactive protein.

determined in $1 \mathrm{~h}$ after injecting an undenatured preparation of human albumin labelled with a radioactive isotope of iodine (usually ${ }^{125} \mathrm{I}$ ). We have shown that TER is increased by up to $300 \%$ in patients in septic shock (Fleck et al. 1985b) and is also increased in patients with various cancers (Raines et al. 1982). There is thus direct evidence of increased loss of albumin to the tissue spaces in these conditions.

There is also considerable evidence that the catabolism of albumin is increased after severe injury (Ballantyne \& Fleck, 1973b; Davies, 1982) and that some cytokines, including IL-1, inhibit albumin synthesis (Mackiewicz et al. 1988). The changes in the rates of catabolism and synthesis of albumin after injury will influence total body albumin in the same direction, i.e. decrease, and although the effects on albumin concentration are unlikely to be observed within the first $24 \mathrm{~h}$ of an injury, if prolonged, would significantly delay the recovery of albumin concentration to normal.

Some years ago we showed that injury led to decreased synthesis of albumin in experimental rabbits (Ballantyne et al. 1973) but not in rats (Caine, 1971).

It should be noted that the injuries were different and of differing degree. We also found a wide range of rate of albumin synthesis in patients in septic shock, from very low to significantly increased, despite the fact that all patients were receiving parenteral nutrition at the time of study (Fleck et al. 1984). 


\section{Nutrition and plasma proteins}

After a few days of total starvation with free access to water the concentration of albumin and total protein is significantly increased, whereas the concentration of retinol-binding protein is decreased (Broom et al. 1986).

Prolonged protein-energy depletion in man sufficient to yield a decrease in bodyweight of $25 \%$ led to only a $7 \%$ decrease in concentration of albumin (Keys et al. 1950). When the increase in plasma volume is taken into account there was no change in the amount of albumin in the circulation.

Patients with anorexia nervosa do not have a low albumin concentration (Bentdal et al. 1988). In contrast, experimental rats fed on a diet from which protein was omitted showed a gradual decrease in albumin concentration (Fleck \& Munro, 1963). In this group of animals protein depletion led to a marked decrease in albumin turnover, which was also noted by Hoffenberg et al. (1966) who suggested that both synthesis and catabolism of albumin were decreased by protein depletion.

Thus, since albumin concentration is influenced slightly, if at all, by protein-energy depletion, but can be significantly decreased during the acute-phase response, albumin concentration should not be used as an index of nutrition in patients (for more detailed discussion, see Fleck, 1988a).

There is increasing evidence that following changes in the concentration of proteins with rapid turnover such as retinol-binding protein and pre-albumin can be of value when attempting to assess the results of nutritional therapy in patients (Fleck, 1988b). It remains important, however, to note that these proteins are also affected by injury (see Fig. 1).

The extent to which the synthesis of acute-phase proteins can be modified by nutrition is, as yet, not clear.

Increased acute-phase proteins, notably CRP, have been observed frequently in cachectic cancer patients, but my colleagues and I have not observed an increase in the concentration of CRP in such patients, or in patients with Crohn's disease, which we could reliably interpret as being in response to total parenteral nutrition estimated to meet the patients' complete requirements for energy and protein and which achieved gain in weight (Glynn et al. 1988).

The possible effects of the acute-phase response and nutritional depletion on the immune response could be important clinically. Some depression of the immune response has been reported in patients after burning injury (Constantian, 1978) and after surgery (Cochran et al. 1972). The suppression of the immune response after trauma has been suggested as being due to activation of suppressor T cells (Munster, 1976).

In our observations on cell-mediated immunity (CMI) in patients with cancer we found that CMI was most severely depressed in patients with the lowest concentrations of albumin and highest concentrations of CRP (Nagendran et al. 1985a,b).

Taking all the factors which could influence albumin distribution and metabolism and, thus, its concentration after injury, it is not surprising that albumin has been found to be a good indicator of prognosis (Anderson et al. 1984).

During an acute-phase response it is likely that TNF, which is identical with cachectin, is released. In chronic conditions this may be a factor causing weight loss.

Also continued release of EP would be likely to lead to increased requirement for energy which if not met could also lead to loss of body tissue. Continued elevation of CRP in a patient is thus an indication of a continuing (or 'chronic') acute-phase response and is likely to be associated with cachexia.

The most appropriate treatment is to remove the cause of the acute-phase response 
(e.g. tumour, sepsis, etc.) and it is the experience of many clinicians that cachectic patients do not respond well to appropriate nutrition until the pathology has been adequately dealt with.

\section{Summary}

1. When assessing the significance of altered plasma protein concentrations the various physiological factors, including posture and hormones which affect the amount and distribution of fluid in the body and the synthesis and catabolism of plasma proteins, must be kept in mind.

2. Although several cytokines, including IL-1 and TNF, are implicated in the acute-phase response, recent evidence is that the synthesis of the major acute-phase proteins (e.g. CRP) is induced by IL-6.

3. The positive acute-phase plasma proteins are useful non-specific indicators of tissue damage.

4. When there is evidence of an acute-phase response (e.g. increased CRP), decreased concentrations of plasma proteins such as albumin, transferrin, retinol-binding protein and pre-albumin cannot be assumed to reflect malnutrition.

5. Plasma albumin concentration can be a good indicator of prognosis.

\section{REFERENCES}

Anderson, C. F., Moxners, K., Meister, J. \& Burritt, B. F. (1984). Mayo Clinic Proceedings 59, 477-483.

Auron, P. E., Webb, A. C., Rosenwasser, L. J., Mucci, L. J., Rich, A., Wolff, S. M. \& Dinarello, C. A. (1984). Proceedings of the National Academy of Sciences, USA 81, 7907-7911.

Ballantyne, F. C. \& Fleck, A. (1973a). Clinica Chimica Acta 44, 341-347.

Ballantyne, F. C. \& Fleck, A. (1973b). Clinica Chimica Acta 46, 139-146.

Ballantyne, F. C., Tilstone, W. J. \& Fleck, A. (1973). British Journal of Experimental Pathology 54, 409-415.

Baltz, M. L., De Beer, F. C., Feinstein, A., Munn, E. A., Milstein, C. P., Clamp, J. R., Davies, A. J. S. \& Pepys, M. B. (1982). Annals of the New York Academy of Sciences 389, 49-75.

Belfrage, S. (1963). Acta Medica Scandinavica Suppl. 395, 1-169.

Bentdal, S. S., Froland, S. S., Askvold, F., Bjoro, K. \& Larsen, S. (1988). Clinical Nutrition 7, 93-99.

Beutler, B. \& Cerami, A. (1987). New England Journal of Medicine 316, 379-385.

Böhme, A. (1911). Deutsche Medizinische Klinik 103, 522-562.

Broom, J., Fraser, M. H., McKenzie, K., Miller, J. B. \& Fleck, A. (1986). Clinical Nutrition 5, 63-65.

Caine, S. (1971). Partial hepatectomy and plasma protein synthesis. PhD Thesis, University of Glasgow.

Casley-Smith, J. R. (1980). In The Cell Biology of Inflammation, vol. 3, pp. 53-82 [G. Weissmann, editor]. Amsterdam: Elsevier/North-Holland Biomedical Press.

Cochran, A. J., Spilg, W. G. S., Mackie, R. M. \& Thomas, C. E. (1972). British Medical Journal 4, 67-70.

Cochrane, C. G. \& Griffin, J. H. (1982). Advances in Immunology 33, 241-306.

Constantian, M. B. (1978). Annals of Surgery 188, 209-215.

Cuthbertson, D. P. (1932). Quarterly Journal of Medicine 25, 233-246.

Cuthbertson, D. P. (1942). Lancet i, 433-437.

Cuthbertson, D. P. \& Tompsett, S. L. (1935). British Journal of Experimental Pathology 16, 471-475.

Davies, J. W. L. (1982). Biological Response to Buming Injury. London: Academic Press.

Dinarello, C. A. (1984). Reviews of Infectious Diseases 6, 51-95.

Fleck, A. (1985). Annals of Clinical Biochemistry 22, 33-49.

Fleck, A. (1988a). Nutrition 4(2), 109-117.

Fleck, A. (1988b). Brisish Journal of Clinical Practice 42, Symp. Suppl. 63, 20-24.

Fleck, A., Colley, C. M. \& Myers, M. A. (1985a). British Medical Bulletin 41, 265-273.

Fleck, A. \& Munro, H. N. (1963). Metabolism 12, 783-789.

Fleck, A., Raines, G., Hawker, F. \& Ledingham, I. McA. (1984). Archives of Emergency Medicine 1(16), 177.

Fleck, A., Raines, G., Hawker, F., Trotter, P. I., Wallace, I. Mc., Ledingham, A. \& Calman, K. C. (1985b). Lancet 1, 781-784.

Ganrot, P. O. (1972). Scandinavian Journal of Clinical and Laboratory Investigation 29, Suppl. 124, 83-88. 
Gauldie, J., Richards, C., Harnish, D., Lansdorp, P. \& Baumann, H. (1987). Proceedings of the National Academy of Sciences, USA 84, 7251-7255.

Glynn, M. J., Powell-Tuck, J. \& Fleck, A. (1988). Clinical Nutrition 7, Special Suppl., 15.

Hoffenberg, R., Black, E. \& Brock, J. F. (1966). Journal of Clinical Investigation 45, 143-152.

Hunter, J. (1794). A Treatise on the Blood, Inflammation and Gunshot Wounds (also published in 1812 by $\mathrm{E}$. Cox of London).

Kampschmidt, R. F. (1981). In Infection: The Physiologic and Metabolic Responses of the Host, pp. 55-74 [M. C. Powanda and P. G. Canonico, editors]. Amsterdam: Elsevier.

Kampschmidt, R. F., Upchurch, H. F., Upchurch, U. F., Eddington, C. L. \& Pulliam, L. A. (1973). American Journal of Physiology 118, 527-531.

Keys, A., Brozek, J., Henscel, A., Mickelson, O. \& Taylor, H. L. (1950). The Biology of Human Starvation, vols. 1 and 2. Minneapolis: University of Minnesota Press.

Koj, A. (1985). In The Acute Phase Response to Injury and Infection, pp. 139-144 [A. H. Gordon and A. Koj, editors]. Amsterdam: Elsevier.

Koj, A., Gauldie, J., Regoeczi, E., Sauder, D. N. \& Sweeney, G. D. (1984). Biomedical Journal 224, $505-514$.

Koj, A. \& Gordon, A. H. (editors) (1985). The Acute Phase Response to Injury and Infection. Amsterdam: Elsevier.

Koj, A., Kurdowska, A., Magielska-Zero, D., Rokita, H., Sipe, J. D., Dayer, J. M., Demczuk, S. \& Gauldie, J. (1987). Biochemical International 14, 553-560.

Laurell, C. B., Kullander, S. \& Thorell, J. B. (1968). Scandinavian Journal of Clinical and Laboratory Investigation 21, 337-343.

Little, R. A. \& Frayn, K. N. (1986). The Scientific Basis for the Care of the Critically Ill. Manchester: Manchester University Press.

Lomedico, P. T., Gubler, V., Hellmann, C. P., Dukovich, M., Giri, J. G., Pan, U.-C. E., Collier, K., Semionow, R., Chua, A. O. \& Mizel, S. B. (1984). Nature 312, 458-462.

Mackiewicz, A., Ganapathi, M. K., Schultz, D., Samols, D., Reese, J. \& Kushner, I. (1988). Biochemical Journal 253, 851-857.

MacLeod, C. M. \& Avery, O. T. (1941). Journal of Experimental Medicine 73, 191-200.

McPhaden, A. R. \& Whaley, K. (1985). British Medical Bulletin 41, 281-286.

March, C. J., Mosely, B., Larsen, A., Cerretti, D. P., Braedt, G., Price, V., Gillis, S., Henney, C. S., Kronheim, S. R., Grabstein, K., Conlon, P. J., Hopp, K. \& Cosman, D. (1985). Nature 315, $641-647$.

Munster, A. M. (1976). Lancet i, 1329.

Myers, M. A. (1987). Aspects of the acute phase response. PhD Thesis, University of London.

Myers, M. A. \& Fleck, A. (1988). British Journal of Experimental Pathology 69, 169-176.

Myers, M. A., Fleck, A., Sampson, B., Colley, C. M. \& Bent, J. (1984). Journal of Clinical Pathology 37, $862-866$.

Nagendran, V., Myers, M. A. \& Fleck, A. (1985a). XIII International Congress of Nutrition, Brighton, Abstr. 78.

Nagendran, V., Myers, M. A. \& Fleck, A. (1985b). XIII International Congress of Nutrition, Brighton, Abstr. 95.

Parving, H. H. \& Gyntelberg, F. (1973). Circulation Research 32, 643-651.

Owen, J. A. (1967). In Advances in Clinical Chemistry, vol. 9, pp. 1-41 [H. Sobotka and C. P. Stewart, editors]. New York: Academic Press.

Raines, G., Calman, K. C., Fleck, A., Trotter, J., Caine, S. C., Gordon, S., Bell, J., McCauley, G. \& Willcox, J. C. (1982). In Clinical Nutrition, pp. 160-165 [R. Wesdorp and D. Soeters, editors]. Edinburgh: Churchill Livingstone.

Rossing, N. (1967). Clinical Science 33, 593-602.

Shenkin, A., Fraser, W. D., Series, J. D., Burns, H. J. G. \& Van Dumme, J. (1988). Clinical Nutrition Special Suppl. 7, 29.

Sunderman, F. W. Jr (1964). American Journal of Clinical Pathology 42, 1-21.

Thompson, W. O., Thompson, P. K. \& Dailey, M. E. (1928). Journal of Clinical Investigation 5, 573-604.

Tillet, W. S. \& Francis, T. Jr (1930). Journal of Experimental Medicine 52, 561-571.

Vahlquist, A., Peterson, P. A. \& Wibell, L. (1973). European Journal of Clinical Investigation 3, $352-362$.

Wannemacher, R. W. Jr, Peckarek, R. S., Thompson, W. L., Curnow, R. T., Beall, F. A., Zenser, T. V., DeRubertis, F. R. \& Beisel, W. R. (1975). Endocrinology 96, 651-661. 